\title{
The implementation of Pikolasa model learning with scientific authentic in junior high school
}

\author{
Siti Khadijah ${ }^{1}$, Diana Nomida Musnir ${ }^{2}$, Suyitno Muslim ${ }^{3}$ \\ \{sitikhadijah_tp09s3@mahasiswa.unj.ac.id ${ }^{1}$, diananomida@gmail.com ${ }^{2}$, suyitno.muslim@yahoo.com ${ }^{3}$ \} \\ ${ }^{123}$ Universitas Negeri Jakarta, Jakarta, Indonesia \\ ${ }^{1}$ Universitas Islam Negeri Syarif Hidayatullah, Jakarta, Indonesia
}

\begin{abstract}
Character and moral values have become the biggest challenge for the everyday Indonesian. The decadence of moral values cannot be separated from the ineffectiveness to inculcate moral values in the family, schools, and society as a whole. This study attempts to describe Islamic Religion Education learning in a more comprehensive way, while emphasizing on the aspect of value using the "PIKOLASA" model and based on authentic-scientific in junior high school. It aims to develop students' ability to intelligently choose the right way to communicate, act, and live in accordance with Islamic Religion Education. The study made use of a qualitative and descriptive method of data analysis. Data was collected by conducting interviews, observation, and analysing documents. The practice of learning Islamic Religious Education using the PIKOLASA Model does not only enable the achievement of cognitive skills, more importantly it enables the attainment of both spiritual and social attitudes.
\end{abstract}

Keywords: Learning model; scientific approach; authentic assessment

\section{Introduction}

The recent immoral attitude in students' life such as brawls, promiscuity, drugs, immorality, pornography, violence against teachers and lots more shows that that schools are no longer creating moral awareness for students to embrace. The Islamic Religion Education is more focused on impacting the knowledge rather than implementing moral values into students, in accordance with learning objectives. Kuboja and Ngussa in their research revealed that there is a great need to balance the assessment of student learning outcomes by putting all domains (cognitive and affective) related to behavioral change rather than just assessing cognitive achievements. [1]

This research is expected to contribute positively to the effort required by students to overcome high complexity of negative values. The PIKOLASA learning model is a learning technique which emphasizes on the evaluating process that will help students in achieving their dreams, communicating correctly, practicing values consciously, and accustoming those values to their everyday life. The developed PIKOLASA model is more meaningful, technological, creative, innovative, scientific, and authentic. This learning model seeks to improve students' ability in exploring and internalizing the existing positive values in their environment and encourage students to live a noble life based on universal values.

The formulation of this research aims at identifying: How to apply the PIKOLASA model to teach Islamic Religion Education as a subject at SMPN 87 South Jakarta? In practical terms, this model is expected to be one of the informative sources and tools that can be used as a value learning model to teach junior high school students Islamic Religion Education. The development of PIKOLASA model can also be referred to the value clarification approach that emerges primarily from humanistic psychology and education movement, which emerges from the ideas and theories of Allport, Maslow, Rogers, and subsequently developed in the works of Raths, Harmin \& Simon, Simon \& Kirschenbaum, and Simon, Howe \& Kirschenbaum. The main focus of the PIKOLASA model, as well as the value clarification approach, is to help students to think 
rationally using their emotional. This model will examine personal behavior patterns of students, clarify and actualize the values inside of them. This is because assessment is a process of selfactualization.

\section{Literature Review}

\subsection{Model of Learning}

Model is a simplified pattern or design used to explain the workings of a real world system or event. [3] The learning model is a theoretical scheme that illustrates an orderly program in formulating learning experiences in order to accomplish characteristic learning objectives like determining the purpose of the subject, analyzing some physical features of the learner, preparing specific instructional goals, selecting learning content, preliminary tests , learning implementation, service support, evaluation, and revision.

\subsection{Scientific approach}

Scientific approach is a type of learning process that focuses on the use of scientific methods in teaching and learning activities. This is based on the learning process carried out by the students and the teachers. The primary aim of this approach is to make students think scientifically, logically, critically and objectively in accordance with the facts. This approach, consist of the following steps: observation, investigation, critical reasoning, hypothesis, and setting up networks for all the subjects.

\subsection{Authentic Assessment}

Authentic Assessment is the measurement of a students' cognitive achievements that are productive, significant and meaningful as contradicts to the multiple choice diversified tests.. The term "assessment" has the same meaning with words like evaluation, measurement, examination, or valuation. While the term "authentic" is the same as genuine, real, valid, or reliable. Authentic assessment is formulated by the teacher or together with the student by engaging student voice. When applying authentic assessment to students' knowledge and skills, a teacher utilizes principles relevant to the construction of knowledge, disciplined inquiry and the value of the achievement beyond the school authentic assessment emphasizes on the ability of students to demonstrate meaningful knowledge. Assessment activities are real performance of knowledge that has been mastered. Hence, authentic assessment is a comprehensive assessment that evaluates the input, and output processes of learning. Authentic assessment is aimed at measuring various skills in various contexts that reflect the real life situation where these skills are applied.. For example, students are assigned to write certain topics, that are applicable to their real life, and participate in the real discussions or book reviews, journals, letters, or some editing process of the writings until it is ready to be published. From the above statements, we can deduce that this model keeps emphasizing on the performance measurement, and this action has been a practice in science that is theoretically mastered. Authentic assessment in the implementation of the 2013 curriculum refers to: 1 Assessment of individual's competency via observation, self-assessment, peer evaluation by students and journals 2. Assessment of knowledge through written and oral tests/ assignments. 3. Assessment of skills through performance evaluation, which is an assessment that requires students to demonstrate a particular competency by indulging in practical tests, projects, and portfolio assessments.

\section{Method}

This research was conducted at the Islamic Religion Education learning process in the State Junior High School 87, South Jakarta. It lasted for 5 months from the period of April to October 
2018. The research method made use of a qualitative approach with descriptive analysis method, which prioritizes the process and meaning/perception problems. This research aims to reveal a variety of qualitative information with accurate and meaningful descriptive-analysis. Data collection techniques used in this study is: 1) interviews, which were conducted on Islamic Religion Education teachers, principals, and students; observations, which were carried out to directly observe the situation, and that which really occurs in Islamic Religion Education using the PIKOLASA model. Observations were carried out systematically in accordance with the framework compiled in class VIII 5; while documentation was carried out to complete data in the form of teacher learning tools, school data, and student report books. Data collected through interviews, observations, and documentation study were then analyzed qualitatively with the model developed by Miles and Huberman, namely data reduction, presentation, drawing conclusions, and verification.[5] Meanwhile, the quantitative data are collected through interview, questionnaire, and observation. The key instrument in this study is the researchers themselves to facilitate the process of adaptation to real conditions as well as possible. All research data can be found in the following link:

(https://mfr.osf.io/render?url=https://osf.io/7sdgx/?action=download\%26mode=render)

\section{Result}

Learning activities are designed to accommodate all competency demands that have been set in accordance with the 2013 curriculum including that of spiritual, social, knowledge and skill. In this research, teachers created several types of activities aimed at enhancing students' ability to choose, communicate, and carry out accustoming values and in order to generate motivation and enthusiasm of students in learning as shown in the table below.

Table 1. Stages of Student Experience in Learning with the PIKOLASA Model

\begin{tabular}{|c|c|}
\hline $\begin{array}{l}\text { Type of } \\
\text { Activity }\end{array}$ & Description \\
\hline Let's reach! & $\begin{array}{l}\text { The Goals or competencies to be achieved after the learning process. In this case, the goals } \\
\text { of spiritual and social attitudes become the main emphasis in the development of materials, } \\
\text { methods, media, student tasks, and assessments, as well as the attainment of these attitudes. }\end{array}$ \\
\hline Let's focus! & $\begin{array}{l}\text { Ice breaking activities,such as movements, songs, listening, games conducted to focus } \\
\text { students' attention before discussing the subject matter. }\end{array}$ \\
\hline Let's observe! & $\begin{array}{l}\text { Students' activities, such as gallery sections and indulging in friendly discussions. Teachers } \\
\text { make use of the poster comment method, to develop students' abilities in choosing good } \\
\text { values. }\end{array}$ \\
\hline Let's ask! & $\begin{array}{l}\text { Students are given the time to make inquiries about the material that will be given to them } \\
\text { in order to reveal their experience in accordance to the related material. This is done in } \\
\text { order to deliver effectiveness. }\end{array}$ \\
\hline Let's read! & $\begin{array}{l}\text { Students pay keen attention as the teacher reads from the verses that are in the subject of } \\
\text { Islamic Religious Education in tarteel using the drill method. After which students are } \\
\text { allowed to recite these verses with friends seated close to them ( } 5 \text { minutes-alternately). }\end{array}$ \\
\hline Let's apply! & $\begin{array}{l}\text { Activities such as demonstrations or practices related to the skills set out in the learning } \\
\text { process of saying gratitude, recitations, and prostration for forgetfulness. In this case, } \\
\text { teachers invite students to the mosque if it is related to prayer and prostration. }\end{array}$ \\
\hline $\begin{array}{l}\text { Let's } \\
\text { investigate and }\end{array}$ & $\begin{array}{l}\text { Discussion activities related to the content of values in the material and identification of } \\
\text { examples of value implementationin the daily life. }\end{array}$ \\
\hline $\begin{array}{l}\text { apply the } \\
\text { value! }\end{array}$ & \\
\hline Let's & It is a reflection of the stories in the module used to build awarenesscontained in Islamic \\
\hline Contemplate! & Religion Education. \\
\hline Let's realize! & $\begin{array}{l}\text { The task for students to observe life phenomenon, related to thediscussed values and } \\
\text { students' assessment of the cases around them. }\end{array}$ \\
\hline Let's practice! & Student are encouraged to carry out educational activities by answering questions to assess \\
\hline
\end{tabular}


Let's

An activity that strengthens students' memory and enables them to memorize and recall

memorize! activities called out in the classroom.

Let'shabituate! Student activities in habituating the practice of valueslearned by students in everyday life. In this case, teachers give individual tasks with the format that has been given related to the behavior that will be instilled in students such as sunnah prayer, reciting the Qur'an, sujud tilawah, literacy, social service etc. These activities are reported periodically to the Islamic Religion Education teacher.

Let's create! Student's activities in creating products that strengthen their competencies, in and outside the classroom. It is done by creating wall magazine, concept maps, and outing up posters containing wise words related to the discussion.

Implementation of PIKOLASA model has been guided and sectioned into module that positively affect some activities learning such as let's reach!, let's focus!, Let's observe!, until let's habituate!. To reach student abilities of habituation the model accommodated many strategies and methods of learning using scientific approach and authentic assessments as shown in the table below.

Table 2. Relation Of The Affection, Authentic Scientific And Ability Level In The PIKOLASA Model.

\begin{tabular}{|c|c|c|c|c|}
\hline $\begin{array}{c}\text { Affection } \\
\text { Level }\end{array}$ & Strategy/Method & $\begin{array}{l}\text { Scientific } \\
\text { Stage }\end{array}$ & PIKOLASA & Modul Activity \\
\hline Receiving & $\begin{array}{l}\text { Icebreaking; Apperception; Poster } \\
\text { Comment; Listening; Video Critic }\end{array}$ & Observing & Choosing & $\begin{array}{l}\text { let's reach! } \\
\text { Let's Focus! }\end{array}$ \\
\hline Responding & $\begin{array}{l}\text { Brain Storming; Question and answer; } \\
\text { Everyone is a teacher here; Small } \\
\text { Group Discussion; The power of Two }\end{array}$ & Questioning & Choosing & $\begin{array}{l}\text { Lets Observe! } \\
\text { Let's ask! }\end{array}$ \\
\hline Valuing & $\begin{array}{l}\text { Poster comment; Video critic; } \\
\text { Problem-based learning; Billboard } \\
\text { rangking; Example nonexample: } \\
\text { Observation; Peer assessment; Self- } \\
\text { assessment }\end{array}$ & $\begin{array}{l}\text { Experimentin } \\
\mathrm{g} \\
\text { Exploring }\end{array}$ & $\begin{array}{l}\text { Choosing } \\
\text { Communicati } \\
\text { ng } \\
\text { Acting }\end{array}$ & $\begin{array}{l}\text { Let's meditate! } \\
\text { Let's realize! }\end{array}$ \\
\hline Organization & $\begin{array}{l}\text { Presentation: Demontration; } \\
\text { Simulation; Project-based learning; } \\
\text { Problem-based learning } \\
\text { Self-Assessment; observation }\end{array}$ & $\begin{array}{l}\text { Associating } \\
\text { Analyzing } \\
\text { Comunicating }\end{array}$ & $\begin{array}{l}\text { Communcatin } \\
\mathrm{g} \\
\text { Acting } \\
\text { Habituating }\end{array}$ & $\begin{array}{l}\text { Let's read! } \\
\text { Let's practice! } \\
\text { Let's simulate! } \\
\text { Let's } \\
\text { demonstrate! } \\
\text { Let's memorize! } \\
\text { Let's apply! } \\
\text { Let's investigate } \\
\text { and apply the } \\
\text { values! }\end{array}$ \\
\hline $\begin{array}{l}\text { Characterizat } \\
\text { ion }\end{array}$ & Portfolio & $\begin{array}{l}\text { Communicati } \\
\text { ng verbal non } \\
\text { verbal }\end{array}$ & $\begin{array}{l}\text { Communicati } \\
\text { ng } \\
\text { Acting } \\
\text { Habituating }\end{array}$ & $\begin{array}{l}\text { Let's practice } \\
\text { Let's create! } \\
\text { Lets habituate! }\end{array}$ \\
\hline
\end{tabular}

Various techniques for evaluating Islamic Religion Education with the PIKOLASA model are as follows:

Table 3. Types and Authentic Assessment Techniques of Islamic Religion Education

\begin{tabular}{lcccccc}
\hline $\begin{array}{c}\text { Assessment } \\
\text { Type }\end{array}$ & $\begin{array}{l}\text { Performance } \\
\text { assessment }\end{array}$ & $\begin{array}{c}\text { Project } \\
\text { Assessment }\end{array}$ & Portfolio & $\begin{array}{c}\text { Written } \\
\text { assessment }\end{array}$ & $\begin{array}{c}\text { Oral } \\
\text { assessment }\end{array}$ & $\begin{array}{c}\text { Attitude } \\
\text { Assessment }\end{array}$ \\
\hline $\begin{array}{c}\text { Assessment } \\
\text { Techniques }\end{array}$ & $\begin{array}{c}\text { checklist; } \\
\text { anecdotal/narative } \\
\text { records; rating } \\
\text { scale; and }\end{array}$ & $\begin{array}{c}\text { observation } \\
\text { (checklist } \\
\text { rating }\end{array}$ & $\begin{array}{c}\text { Observation } \\
\text { (checklist } \\
\text { rating scale) }\end{array}$ & $\begin{array}{c}\text { Short } \\
\text { answer; } \\
\text { scale) }\end{array}$ & Essay & Observation; \\
multiple & & $\begin{array}{c}\text { Direct } \\
\text { interview; } \\
\text { assessment; } \\
\text { peer } \\
\text { assessment }\end{array}$ \\
\hline
\end{tabular}




\section{Discussion}

The PIKOLASA model provides opportunities for students to locate and determine values, which have been a foundation of their attitudes and behavior. Seçken and Alsan in their research found that the implementation of constructivist learning, positively contributes to students' understanding. [7] The values in PIKOLASA model emphasize more on affective aspects as students are required to be able to live and apply implicit and explicit messages from the values contained in the Islamic Religion Education learning. Dakir et all research revealed that a good level of Islamic knowledge has increased students internalization level. Similarly, the influence of the social environment has a significant impact on the average level of character internalization on students.[8] The method used in the PIKOLASA value model can be in the form of dialogue, writing, discussion, portfolio, role-playing games, simulations, contrived or real value-laden situations, in-depth self-analysis exercises, sensitivity activities, out-of-class activities, small group discussions, piloting, value analysis, interviews, jurisprudence, and value inquiry. These activities are considered very suitable to be applied to a self-awareness program related to the mission of students' values, morals, attitudes, and behavior. The PIKOLASA model encourages students to spend more time pondering and questioning societal values as a whole. Çubukcu research revealed that values can be included in the curriculum and activities that support the development of the hidden curriculum in the learning process, in order to internalize good values in students.[9]

A research conducted by Rastegar and Fatemi revealed that there is a significant positive relation between self-actualization and student creativity. Students who have a high selfactualization score tend to have high emotional intelligence.[10] This approach seeks to help students assess their own feelings and actions, encourage awareness to identify their values and that of others, help students to communicate honestly and openly, help them to assess their own feelings, values, and behavior.[10] Manni, Sporre and Ottander's research revealed that students' expressions toward values and emotions have a positive relation of a complex understanding of the ecological, economic and social aspects of the continuity of human life.[11] Thus the PIKOLASA model challenges teachers to be able to create values conflict so that students are capable to find their own values. Cavilla in his research revealed that students' academic outcomes, motivation, and metacognition increased when students were able to assess themselves through student reflection.[12] This approach encourages students to get used to express reasons in justifying a value that has been built.

The model attempts to reduce behavioral inconsistencies caused by confusion and the inability of students to choose, communicate, and habituate. The model has accommodated humanist learning with existentialism and phenomenology philosophy which adopts a holistic approach to human existence through investigating meaning, values, freedom, tragedy, personal responsibility, human potential, spirituality, and self-actualization.[13] The PIKOLASA model tries to give a nuance of learning that is expected to improve students' ability to respond to situations in their environment rationally and emotionally. This is because the ability to respond to these rational and rational environments can develop critical awareness.[14]

The learning model has also implemented meaningful learning tactics based on Ausubel's meaningfulness requirements. Learning that emphasizes on attitude aspect will touch a lot of students' emotions which will make what is absorbed to become meaningful. There are three virtues of meaningful learning, namely: (a) Longer information can be remembered,[15] (b) facilitate the next learning process for a similar subject matter, and (c) make it easier to learn similar things even though they have forgotten. This can be seen in the results of a significant pretest and posttest. Learning activities are designed to accommodate all competency demands set in accordance with the 2013 curriculum which includes Spiritual, social, knowledge, and skills competencies in a balanced manner. 


\section{Conclusion}

Based on the formulation of the problem, purpose of the study and discussion on the obtained results, it can be concluded that: The implementation of learning with the PIKOLASA model provides a new paradigm for Islamic Religious Education teachers, thereby, making learning easy for student's not only in the with regards to knowledge and skills, but also with that of spiritual and social attitudes. Learning with the PIKOLASA model provides various types of experiences that emphasizes on Islamic Religion Education and students' spiritual and social attitudes. The model challenges Islamic Religious Education teachers to be more creative in developing learning goals aimed at inculcating proper character traits in students,.

\section{References}

[1] Cavilla, D.: The Effects of Student Reflection on Academic Performance and Motivation. SAGE Open, 7(3), 2158244017733790. (2017).

[2] Çubukçu, Z.: The effect of hidden curriculum on character education process of primary school students. Educational Sciences: Theory and Practice, 12(2), 1526-1534. (2012).

[3] Dahar, R. W.: Teori belajar. Jakarta: Erlangga. (1989).

[4] Dakir, J., Othman, M. Y. H., Tamuri, A. H., Stapa, Z., Yahya, S. A., Ismail, S., \& Maheran, I.: Islamic education and level of character internalization of secondary school students in Malaysia. Mediterranean Journal of Social Sciences, 6(4), 602. (2015).

[5] Hampson, S. E., \& Colman, A. M.: Individual differences and personality. Longman Publishing Group. (1995).

[6] Huitt, W.: The information processing approach to cognition. Educational Psychology Interactive, 3(2), 53. (2003).

[7] Kuboja, J. M., \& Ngussa, B. M.: Affective learning and cognitive skills improvement: Experience of selected schools in Arusha, Tanzania. International Journal of Academic Research in Progressive Education and Development, 4(2), 38-53. (2015).

[8] Manni, A., Sporre, K., \& Ottander, C.: Emotions and values-A case study of meaning-making in ESE. Environmental Education Research, 23(4), 451-464. (2017).

[9] Miles, Mathew B. dan A. Michael Huberman: Analisis data Kualitatif, Terjemahan, Tjetjep Rohendi Rohidi Jakarta: Universitas Indonesia-UI Press, , h. 18, (1992)

[10] Murad, A. V.: The Process of Values Clarification, Formation and Inculcation. Pakistan Journal of Social and Clinical Psychology, 12(2), 53. (2014).

[11] Pribadi, Benny A., : Model Desain Sistem Pembelajaran Jakarta: Dian Rakyat h. 86 (2010)

[12] Rastegar, M., \& Fatemi, M. A.-S.: The Interplay of Self-Actualization, Creativity, Emotional Intelligence, Language and Academic Achievement in Gifted High School Students. International Journal of Psychology, 11(1). (2017).

[13] Reigeluth, Charles M.,: Instructional-Design Theories an Model: An Overview of Their Corrent Status (London, Lawrence Associates Publishers,), h. 21 (2009)

[14] Seçken, N., \& Alsan, E.: The effect of the constructivist approach on students' understanding of the concepts related to hydrolysis. Procedia-Social and Behavioral Sciences, 15, 235-240. (2011).

[15] Zuriah, N. (n.d.): Pendidikan Moral dan Budi Pekerti dalam Perspektif Perubahan, Jakarta: Bumi Aksara, Cet. II. (2008). 